\title{
Insect Pheromone Research in South America
}

\author{
Jan Bergmann, ${ }^{a}$ Andrés González ${ }^{b}$ and Paulo H. G. Zarbin ${ }^{* c}$ \\ ${ }^{a}$ Instituto de Química, Pontificia Universidad Católica de Valparaíso, Avda. Brasil 2950, Valparaíso, Chile \\ ${ }^{b}$ Facultad de Química, Universidad de la República, Avda. Gral. Flores 2124, Montevideo, Uruguay \\ 'Departamento de Química, Universidade Federal do Paraná, 81531990 Curitiba-PR, Brazil
}

As pesquisas com feromônios de insetos tem uma longa e rica história, construída, primariamente, pelos estudos conduzidos no hemisfério Norte. Não é surpresa que estes estudos tenham apontado, em grande parte, para espécies relevantes dessas regiões do mundo, na maioria pragas agrícolas e florestais. As investigações com feromônios nos países da América do Sul vieram somente algumas décadas atrás, apesar da sua forte dependência agrícola e, consequientemente, no manejo de pragas. Nos últimos 20 anos, fatores econômicos, ambientais e técnicos têm caminhado juntos para gerar um pequeno, mas crescente, número de ecologistas químicos trabalhando na química e biologia dos feromônios na América do Sul. Neste artigo, foram compilados os resultados desta tendência. Foram revisados os estudos feitos com feromônios nos quais os cientistas da América do Sul têm participado em parceria com cientistas estrangeiros, majoritariamente grupos de química, como também os estudos realizados dentro da região. O principal objetivo são as pesquisas que envolvem a caracterização dos feromônios de espécies nativas, as quais compreendem as ordens mais importantes como Lepidoptera, Coleoptera, Heteroptera e Himenoptera. É também apresentada uma meta-análise, incluindo a distribuição geográfica, a tendência dos trabalhos de colaboração ou independente, e a evolução nos últimos 20 anos dos artigos publicados na área. Finalmente, é enfatizada a importância do esforço coordenado para promover o avanço deste campo na América Latina, através do respaldo e colaboração internacional dentro da região. Esta meta deverá ser alcançada através de uma organização acadêmica regional, incumbida da realização contínua de encontros científicos.

Insect pheromone research has a long and rich history built up primarily by studies conducted in the Northern hemisphere. Not surprisingly, these studies have largely targeted species relevant to these regions of the world, for the most part agricultural and forest pests. Pheromone research in South American countries came a few decades behind, albeit their strong dependence in agriculture and therefore in pest management. In the last 20 years, a combination of economic, environmental and technical factors have come together to generate a small but rising number of chemical ecologists working in pheromone chemistry and biology in South America. In this article we summarize the results of this trend. We review pheromone studies in which South American scientists have participated in collaboration with foreign scientists, mostly chemistry groups, as well as the ever-growing number of studies carried out completely within the region. We have focused mainly in research involving the characterization of pheromones from native species, which involve the most important insect orders, namely Lepidoptera, Coleoptera, Heteroptera and Hymenoptera. We also present a simple meta-analysis including geographical distribution, trends in collaborative or independent work, and a 20-year evolution of published articles in the field. Finally, we emphasize the importance of a coordinated effort to further promote the growth of this field in Latin America, through the endorsement of international collaborations within the region. Such goal would be facilitated by a regional academic organization, which would in turn initiate the occurrence of regular scientific meetings.

Keywords: pheromone, chemical ecology, semiochemicals

\footnotetext{
*e-mail: pzarbin@quimica.ufpr.br
} 


\section{Introduction}

Agriculture and forestry are important factors in South American economies. In 2006, the net output of the agricultural sector contributed between $4 \%$ (Chile) and $21 \%$ (Paraguay) to the gross domestic product (GDP) of the respective country. ${ }^{1}$ When considering furthermore the related industries and services, it becomes clear that a great part of production and employment in South America depends on agriculture and forestry.

The agricultural production in all South American countries is threatened by a number of pests, which are in most cases controlled by the application of pesticides. However, the often indiscriminate use of these chemical agents has numerous negative side effects, such as development of resistance in target organisms, adverse effects to humans (be it field workers or end-consumers), or, in general terms, altered ecosystems. The increasing public concern about these issues and the restrictions imposed by importing countries have led to the adoption of integrated pest management (IPM) strategies in many cases and countries. IPM integrates chemical, biological, and agrotechnical methods of pest control, trying to balance costs and benefits for producers, society, and environment. Insect pheromones are used in IPM methods and the state of the art of their use in Latin American agriculture has been reviewed recently. ${ }^{2}$

Pheromones are naturally occurring chemicals which are produced and released by an organism in order to transmit information to another individual of the same species. The first chemical characterization of a pheromone dates back to 1959, when Butenandt published the identification of the sex pheromone of the silk moth, Bombyx mori, as (10E,12Z)-10,12-hexadecadien-1-ol, using the extracts of about 500,000 moths. ${ }^{3}$ This huge amount of individuals was necessary due to the extremely small amounts of pheromone produced by each insect. Since then, pheromones of several thousand insect species have been identified, greatly facilitated by the development of microchemical methods and sensitive analytical equipment. ${ }^{4}$ The first chemical characterization of a pheromone with the participation of South American scientists was accomplished 1979, when researchers from the United States and Great Britain published the identification of the main component of the trail pheromone of the leaf-cutting ant Atta sexdens rubropilosa together with colleagues from Paraguay and Brazil. ${ }^{5}$ Scientific output from South American researchers in the field of Chemical Ecology has increased rapidly over the last two decades, with Brazil clearly taking the lead. The Brazilian Meetings of Chemical Ecology, held biannually since 1999, have established themselves as a forum for
South American and international researchers to discuss their latest research results.

In this article, the research on insect pheromones done by or in collaboration with South American groups is reviewed. The main focus is on the chemical identification of pheromones of insect species present in South America, but selected related topics will also be discussed, and conclusions and an outlook will be presented.

\section{Overview}

To get an overview of the research articles related to insect pheromones published during the last two decades, a database search in the Science Citation Index Expanded (SCI Expanded) was performed, using the Web of Science. ${ }^{6}$ The database was consulted for the period 1988 until December 2008, entering the following search criteria: the term "pheromon*" as search topic to be present in title, keywords, or abstract, and the authors address containing the name of one of the following countries: Argentina, Bolivia, Brazil, Colombia, Chile, Ecuador, Paraguay, Peru, Uruguay, or Venezuela. The Boolean operator AND was used for the search topic and each of the countries. For the following classification of the articles, the title and the abstract were consulted. In case of doubt, the whole paper was read.

A total of 438 articles were found, of which 177 were classified as "not relevant", as they did not have insect pheromones or insect chemical communication as the central subject. The remaining 261 articles were analyzed focusing on different aspects, as follows. According to the year of publication, it can be seen that scientific production has increased from 1 or 2 articles per year in the late $80 \mathrm{~s}$, to about 20 to 30 articles published annually by South American researchers (Figure 1). When looking at the participating countries, it becomes clear that Brazil has been by far the most productive country (Figure 2), followed by Argentina, Venezuela and Chile. With 187 articles published, Brazil alone produced 2.5-fold more papers than all other countries together.

In order to analyze in more detail the topics addressed in the articles, they were grouped into different categories

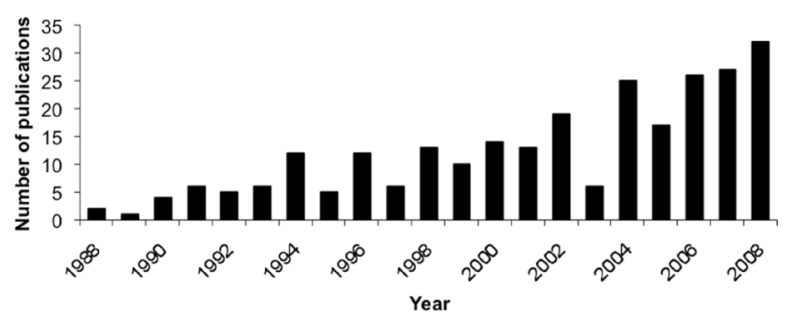

Figure 1. Number of articles published per year. 


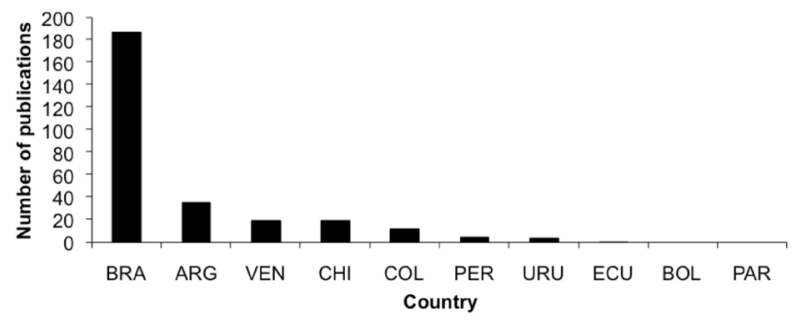

Figure 2. Number of articles published per country.

as follows: (1) Chemical identification of a pheromone; (2) chemical identification of compounds without or with inconclusive behavioral data; (3) behavioral data for unknown compounds (from extracts or live insects); (4) behavioral data for known compounds (excluding the first identification); (5) synthesis of pheromones; (6) other topics (e.g. chemical defenses, bioassay techniques, biosynthesis, pheromone gland ultrastructure, previous review articles, etc.). The number of articles in each category is shown in Table 1, and it can be seen that they are more or less evenly distributed.

Table 1. Classification of the articles. For categories 1-6, see text

\begin{tabular}{lccccccc}
\hline & 1 & 2 & 3 & 4 & 5 & 6 & Total \\
\hline ARG & 4 & 5 & 17 & 2 & 1 & 6 & 35 \\
BOL & 0 & 0 & 0 & 0 & 0 & 0 & 0 \\
BRA & 26 & 32 & 27 & 35 & 36 & 31 & 187 \\
CHI & 2 & 2 & 2 & 10 & 2 & 1 & 19 \\
COL & 4 & 0 & 1 & 5 & 0 & 1 & 11 \\
ECU & 0 & 0 & 1 & 0 & 0 & 0 & 1 \\
PAR & 0 & 0 & 0 & 0 & 0 & 0 & 0 \\
PER & 1 & 0 & 0 & 1 & 0 & 2 & 4 \\
URU & 1 & 0 & 0 & 2 & 0 & 0 & 3 \\
VEN & 1 & 2 & 7 & 4 & 0 & 5 & 19 \\
Total & 39 & 41 & 55 & 57 & 39 & 46 & 279 \\
\hline
\end{tabular}

An interesting point to analyze is the extent of collaboration in which South American scientists are engaged. Although interaction between groups on the national level is the rule, regional collaborations between South American groups are scarce, as is reflected by the low number of joint publications. Only 18 out of the total 261 articles (i.e., 7\%) were published jointly by authors from two or more South American countries. In sharp contrast to that, 33 out of the 39 articles (85\%) from category 1 (identification of pheromones), are published in collaboration with international scientists, mainly from the USA and European countries (Figure 3A). A possible explanation for this fact is that there are few chemical groups doing pheromone work in South America, but at the same time many agronomists, biologists and/or entomologists are engaged in pheromone research, with the consequence that they have to seek the chemical expertise abroad. This is corroborated by the number of articles from group 3 (behavioral evidence for pheromones without chemical identification), where 44 out of 55 articles (80\%) are published by South American scientists without foreign collaboration (Figure 3B). Synthesis of pheromones (articles in category 5) is almost exclusively done in Brazil (36 out of 39 articles; 92\%), which also points to the fact that only few chemistry groups are doing pheromone work in the other countries. Certainly a critical point is the lack of sophisticated analytical equipment, which is often needed for the identification of minute amounts of natural products. Collaboration with foreign groups, in which this equipment is present, is therefore mandatory in many cases.

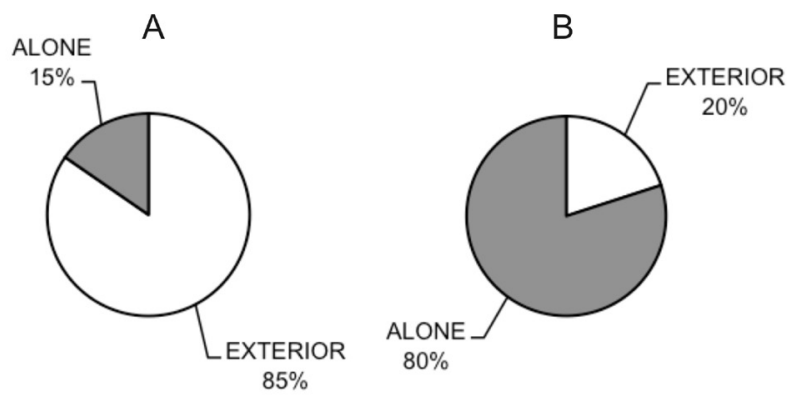

Figure 3. Percentage of articles published in collaboration with foreign groups (white area) or as independent studies (dark area), A, from category $1 ; \mathrm{B}$, from category 3 .

\section{Identification of Behaviorally Active Com- pounds}

\subsection{Lepidoptera}

Lepidoptera is the best-studied insect order with relation to pheromones, with data available for several hundred species. ${ }^{7}$ Intraspecific sex attractants are usually produced by females in a gland located near the ovipositor at the tip of the abdomen, and consist of blends of long-chain alcohols, acetates, or aldehydes, with varying degrees of insaturation. Another major class of lepidopteran sex pheromones are represented by long-chain, unsaturated hydrocarbons and epoxides, as are used by members of the families Geometridae, Noctuidae, Arctiidae, and Lymantriidae. ${ }^{8}$ Species specificity is achieved by the use of blends of several components, in which even trace compounds may have a crucial role. As unnatural isomers often show inhibitory activity, a rather small set of compounds is sufficient for maintaining specificity. This panorama makes the identification and the use of pheromones in pest control an analytically and synthetically challenging task. Trace 
compounds, often accompanied by relatively great amounts of isomers, must be identified, and synthetic compounds must be almost free of non-natural (geometric) isomers.

The lepidopteran pheromones identified with the participation of South American researchers are listed in Table 2. The abbreviations used for the pheromone compounds are in the commonly accepted format, indicating geometry and position of double bond(s), followed by the chain length and functional group. For example, (Z)-11tetradecenol is abbreviated as " $\mathrm{Z11}-14: \mathrm{OH}$ ".

\subsection{Coleoptera}

Beetles are the most diverse group of animals on Earth. They have colonized virtually all terrestrial and freshwater ecosystems, with a remarkable variety of natural histories, ecological interactions and anatomical traits. Their chemistry is not an exception, and such chemical diversity has likely played a role in the phyletic success of the group. Beetles produce defensive chemicals and pheromones using all major biosynthetic pathways. The chemistry, biochemistry, ecological value and phyletic distribution of beetle semiochemicals have been reviewed comprehensively. ${ }^{27}$

Several beetle species, both native to the region and imported, are serious pests in tropical, sub-tropical and temperate regions of South America. The participation of South American scientists in the chemical identification of beetle pheromones has been restricted to eight species of the economically important families Cerambycidae, Curculionidae, Scarabeidae and Scolytidae (presented in this order). Coleopteran pheromones are often structurally complex and they are produced in minute amounts, which may explain the fact that in the three older reports (1994 to 2000) the chemical part of the study was completed in countries outside South America. On the other hand, the five

Table 2. Overview of lepidopteran pheromones identified

\begin{tabular}{|c|c|c|c|c|}
\hline Species & Family & Pheromone & Ratio & Reference \\
\hline Argyrotaenia pomililiana & Tortricidae & $\begin{array}{l}\text { Z11-14:Ac } \\
\text { Z11-14:Ald }\end{array}$ & $\begin{array}{c}100 \\
5\end{array}$ & 9 \\
\hline Argyrotaenia sphaleropa & Tortricidae & $\begin{array}{c}\text { Z11-14:Ald } \\
\text { Z11,13-14:Ald } \\
\text { Z11-14:Ac } \\
\text { Z11,13-14:Ac }\end{array}$ & $\begin{array}{c}1 \\
4 \\
10 \\
40\end{array}$ & 10 \\
\hline Bucculatrix thurberiella & Lyonetiidae & $\begin{array}{l}Z 9-14: \mathrm{ONO}_{2} \\
Z 8-13: \mathrm{ONO}_{2}\end{array}$ & $\begin{array}{c}100 \\
2\end{array}$ & 11 \\
\hline Diatraea saccharalis & Pyralidae & Z9,E11-16:Ald & & 12 \\
\hline Ecdytolopha aurantiana & Tortricidae & $\begin{array}{l}E 8-12: \mathrm{Ac} \\
E 8-12: \mathrm{OH}\end{array}$ & $\begin{array}{c}100-10 \\
1\end{array}$ & 13 \\
\hline Helicoverpa gelotopoeon & Noctuidae & $\begin{array}{l}\text { 16:Ald } \\
\text { Z9-16:Ald }\end{array}$ & $\begin{array}{c}100 \\
84\end{array}$ & 14 \\
\hline Lonomia oblique & Saturniidae & $\begin{array}{l}E 11-16: \mathrm{Ac} \\
E 11-16: \mathrm{OH}\end{array}$ & $\begin{array}{c}100 \\
35\end{array}$ & 15 \\
\hline Megalophanes viciella & Psychidae & 8:iPr & - & 16 \\
\hline Neoleucinodes elegantalis & Crambidae & $\begin{array}{c}E 11-16: \mathrm{OH} \\
Z 3, Z 6, Z 9-23: \mathrm{H}\end{array}$ & $\begin{array}{c}100 \\
5\end{array}$ & 17 \\
\hline Phtheochroa (Bonagota) cranaodes & Tortricidae & E3,Z5-12:Ac & - & 18 \\
\hline Phyllocnistis citrella & Gracillaridae & $\begin{array}{c}\text { Z7,Z11,E13-16:Ald } \\
\text { Z7,Z11-16:Ald } \\
\text { Z7-16:Ald }\end{array}$ & $\begin{array}{c}30 \\
10 \\
1\end{array}$ & 19,20 \\
\hline Scrobipalpuloides (Tuta) absoluta & Gelechiidae & $\begin{array}{c}E 3, Z 8, Z 11-14: A c \\
E 3, Z 8-14: A c\end{array}$ & $\begin{array}{l}90 \\
10\end{array}$ & $21,22,23$ \\
\hline Spodoptera frugiperda & Noctuidae & $\begin{array}{l}Z 7-12: A c \\
E 7-12: A c \\
Z 9-14: A c\end{array}$ & $\begin{array}{c}1 \\
1 \\
100\end{array}$ & 24 \\
\hline Stenoma cecropia & Elachistidae & $\begin{array}{l}Z 9, E 11,13-14: \text { Ald } \\
Z 9, E 11-14: \text { Ald }\end{array}$ & $\begin{array}{l}83 \\
17\end{array}$ & 25 \\
\hline Tecia solanivora & Gelechiidae & $\begin{array}{c}E 3-12: \mathrm{Ac} \\
\text { Z3-12:Ac } \\
\text { 12:Ac }\end{array}$ & $\begin{array}{c}100 \\
1 \\
20\end{array}$ & 26 \\
\hline
\end{tabular}


newer reports (2003-2007) include pheromone chemical studies mostly or entirely done in a South American country (Argentina, Brazil and Chile) (see Figure 4 for an overview). This trend is most likely explained by an improvement in the expertise and analytical equipment available in some South American countries with longer tradition and/or higher public investment in science and technology during recent years.

\subsubsection{Migdolus fryanus (Cerambycidae)}

Working in collaboration with Brazilian entomologists, Leal an co-workers identified the sex pheromone of the long horn beetle $M$. fryanus, a sugarcane pest restricted to South America. ${ }^{28}$ The females emit two sex-specific compounds, $N$-(2'S)-methylbutanoyl (2S)-methylbutylamine (1) and $\mathrm{N}$-formyl L-isoleucine methyl ester (2). Only the former proved active in field tests, while the amino acid derivative was inactive both alone and when combined with the active component. This was the first coleopteran pheromone characterized with participation of South American scientists. Interestingly, it was also the first report of a long-range sex pheromone emitted by females in the family, and, moreover, the first amide with pheromonal activity.

\subsubsection{Dynamis borassi (Curculionidae)}

With participation of Colombian researchers, the male aggregation pheromone of this South American palm weevil was reported as $(4 S, 5 S)$-4-methyl-5-nonanol (3). ${ }^{29}$ While insect collection and field testing were done in Colombia, all the chemical work was conducted in Canada. The antennae of $D$. borassi males and females responded to the compound, which was not attractive on its own but in combination with host volatiles (sugarcane). GC-EAD and field tests indicated a cross-response with other palm weevil aggregation pheromones of similar structure (5-methyl-4octanol and 6-methyl-2-hepten-4-ol).

\subsubsection{Pseudopiazurus obesus (Curculionidae)}

Zarbin and co-workers reported the behavioral response of adult $P$. obesus, a Brazilian pest of papaya, to several odor sources in a Y-tube olfactometer. ${ }^{30}$ Both males and females were significantly attracted to a combination of volatiles released by the males and the host plant, suggesting the existence of a male-produced aggregation pheromone acting synergistically with host volatiles. Analysis of the volatiles from males and females revealed three male-specific compounds, $(1 R, 2 S)$-(+)-grandisal (4), $(1 R, 2 S)-(+)$-grandisol (5), and a yet unidentified component. While these compounds are certain candidates for a male-aggregation pheromone in P. obesus, field tests have not been reported yet.

\subsubsection{Sphenophorus levis (Curculionidae)}

This South American weevil is a serious pest of sugarcane in Brazil. Zarbin and co-workers reported the analysis of airborne volatiles produced by males and females, which resulted in the identification of a single male-specific compound, $(S)$-2-methyl-4-octanol (6). ${ }^{31}$ Both optical isomers were synthesized from $(R)$ - and (S)-2,2-dimethyl-1,3-dioxolane-4-methanol, respectively, and the absolute configuration of the natural alcohol was established by enantioselective gas chromatography. Preliminary laboratory bioassays suggested that the alcohol, which has been identified also from other curculionid species, is active as an aggregation pheromone.

\subsubsection{Hylamorpha elegans (Scarabeidae)}

Quiroz and co-workers reported that the females of this Chilean scarab beetle emit sex pheromones that attracts males both in the laboratory and field,,$^{32}$ an apparently common feature of the Rutelinae subfamily. ${ }^{33}$ The authors found two female-specific volatiles, 1,4-benzoquinone (7) and 1,4-hydroquinone (8), which are structurally related to sex pheromones of species of the Melolonthinae subfamily. While none of the quinones were attractive alone, field data showed that a 1:1 mixture of 1,4-benzoquinone and the essential oil of a host plant, Nothofagus obliqua, was marginally attractive.

\subsubsection{Phyllophaga cuyabana (Scarabeidae)}

A 1:1 mixture of phenol (9) and $p$-cresol (10) was identified as the sex pheromone released by females of $P$. cuyabana, a soybean pest endemic to Brazil. A synthetic mixture was proven to be attractive towards males in the field. ${ }^{34}$

\subsubsection{Strategus aloeus (Scarabaeidae)}

The male-produced aggregation pheromone from this rhinoceros beetle (subfamily Dynastinae) was reported with participation of Colombian scientists. ${ }^{35}$ The study was done simultaneously with a related species from Papua New Guinea, Scapanes australis. This work provides a good example of the use of SPME in the analysis of insect semiochemicals, without the problems associated with solvent impurities or concentration steps. The authors identified highly volatile male-specific compounds both in S. australis, 2-butanol (11) and 3-hydroxy-2-butanone (12), and in S. aloeus, 2,3-butanediol (13), 2-butanone (14), 3-pentanone (15) and sec-butyl acetate (16). Such high volatility had hampered previous attempts to characterize these pheromones by volatile collection on solid adsorbents. Synthetic mixtures of the identified volatiles from both species were active in field and olfactometer bioassays. 


\subsubsection{Platypus mutatus (Scolytidae)}

This ambrosia beetle is native to South America and is distributed in tropical, subtropical and temperate regions of the continent. The adults bore tunnels in the trunk of standing trees, causing damage to important cultivated species, particularly poplar trees (Populus deltoides) in Argentina. Audino and co-workers reported the analysis of head-space volatiles from artificially infested galleries in poplar wood, finding the terpenes $(S)$-6-methyl-5hepten-2-ol (17) (sulcatol) and 6-methyl-5-hepten-2-one (18) (sulcatone), which were absent from the volatiles of uninfested galleries. ${ }^{36}$ Behavioral data indicated that this putative pheromone attracts more females than males, suggesting a sexual rather than an aggregation function. Both compounds elicited behavioral and EAG responses by females. The same group reported later that a third compound, 3-pentanol, identified from volatiles emitted by males was attractive to females. ${ }^{37}$

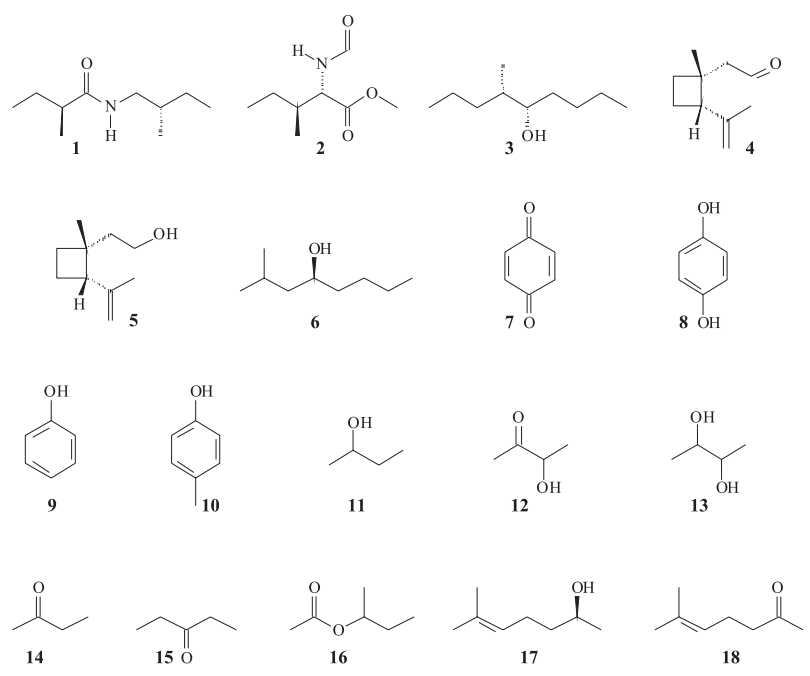

Figure 4. Coleopteran pheromones identified with participation of South American researchers.

\subsection{Hymenoptera}

Hymenoptera is a large insect order, comprising approximately 120,000 species, which show a great biological diversity. Most species are solitary, but some wasps and bees, and all ants live in highly complex societies. The most recent results of studies of the chemical communication systems of hymenopteran species have been reviewed. ${ }^{38}$

\subsubsection{Acromyrmex subterraneus subterraneus (Formicidae, Myrmicinae)}

Leafcutter ants (Acromyrmex and Atta spp.) are distributed in the warmer regions of Central and South America. They feed upon fungi, which they cultivate with fresh-cut plant material (hence their name). Some species are serious pests due to defoliation of agricultural plantations. In collaboration with British scientists, chemists from Brazil identified the ester methyl 4-methylpyrrole-2carboxylate (19) as the trail pheromone produced in the venom glands of $A$. subterraneus subterraneus workers. The same compound and function had been characterized before in other leaf cutter ants (see 3.3.2.), either alone or in combination with alkylated pyrazines. Synthetic samples of the ester showed similar activity as venom gland extracts in trail-following assays. ${ }^{39}$

\subsubsection{Atta laevigata and Atta bisphaerica (Formicidae, Myrmicinae)}

The main component of the trail pheromone produced in the venom gland of Atta laevigata has been identified by Brazilian researchers as methyl 4-methylpyrrole-2carboxylate (19), while the venom gland of A. bisphaerica additionally contained 3-ethyl-2,5-dimethylpyrazine (20)..$^{40}$

\subsubsection{Pogonomyrmex vermiculatus (Formicidae, Myrmicinae)}

Harvester ants of the genus Pogonomyrmex are commonly found in arid and semi-arid habitats over the entire American continent. Interestingly, the South American species $P$. vermiculatus does not show group foraging behavior, as opposed to congeneric North American species. Chilean researchers investigated the ability of workers of $P$. vermiculatus to produce and follow a trail pheromone. ${ }^{41}$ The results showed that alkylated pyrazines are produced in the poison gland and that these compounds (known trail pheromones of other myrmicine species) elicit trail following. Based on these findings, possible explanations for the solitary foraging behavior are presented.

\subsubsection{Pachycondia (Termitopone) marginata (Formicidae, Ponerinae)}

With participation of Brazilian entomologists, Holldobler and co-workers reported that the termite-hunting ant $P$. marginata contains a mixture of monoterpenes and the monoterpenic alkaloid actinidine $\mathbf{2 1}$ in the pigydial gland. ${ }^{42}$ The gland extracts, in combination with visual displays by the recruiting ant, elicited strong recruitment and trail-following behaviour, as did the major gland component, (S)-citronellal (22).

\subsubsection{Trigona recursa (Apidae)}

Stingless bees of the genus Trigona are widely distributed in Brazil. Foraging workers of T. recursa lay scent trails to guide their nestmates to food sources. The 
source of this trail pheromone could be located in the labial gland..$^{43}$ Upon chemical analysis of the contents of this gland, hexyl decanoate (23) was identified as the main volatile component, together with minor amounts of related esters. ${ }^{44}$ Synthetic hexyl decanoate elicited trail following behavior in inexperienced bees, confirming this compound to be an important part of the trail pheromone, however, the results suggested that the minor compounds may play a synergistic role in eliciting trail following behavior.

\subsubsection{Trigona spinipes (Apidae)}

Similar to T. recursa, foragers of this species mark the trail to a food source by depositing saliva. The labial gland, but not the mandibular gland, was shown to contain octyl octanoate (24), and in bioassays this compound elicited trail-following in inexperienced bees. ${ }^{45}$ The single compound was as active as the labial gland extract, suggesting it to act without synergists, as opposed to the observations made in $T$. recursa.

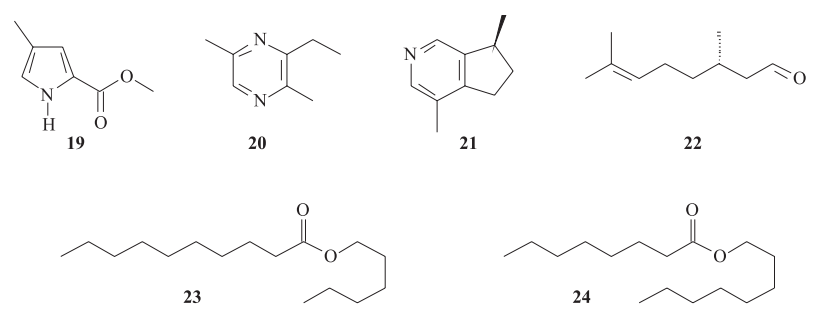

Figure 5. Hymenopteran pheromones identified with participation of South American researchers.

\subsection{Heteroptera}

Some heteropteran species ("true bugs") are serious pests of crops in South America. For example, soybean plantations are most severely affected by the attack of the pentatomid ("stink bug") species Piezodorus guildinii, Euschistus heros, Nezara viridula, and, to a lesser extent, Thyanta perditor and Acrosternum aseadum. Tibraca limbativentris is a pest of paddy rice in Argentina, Brazil, and Uruguay, and the coreid ("leaf-footed bug") Leptoglossus zonatus damages corn and other plantations in Brazil. The pheromone chemistry of Heteroptera has been reviewed comprehensively ${ }^{46}$ and also with a focus on neotropical species ${ }^{47}$ and here we will only refer to examples which are within the scope of the present review.

Members of some true bug families are characterized by well-developed scent glands from which irritant secretions are released. When molested, adult bugs react by discharging volatile secretions from their ventral metathoracic gland. In Leptoglossus zonatus, these secretions were shown to act as an alarm pheromone (see 3.4.1.). In this and several other neotropical stink bug species the chemical composition of the contents of metathoracic gland was studied and the main components are generally aldehydes such as $(E)$-2-hexenal (25), (E)-4-oxo-2-hexenal (26), (E)-2-octenal (27), nonanal (28), (E)-2-decenal (29), or (E)-4-oxo-2-decenal (30), and also may contain $n$-alcanes as surfactants. ${ }^{48-50}$ Pentatomid sex pheromones are usually produced by males and are attractive to females. Neotropical species from which sex pheromones have been identified so far include T. perditor, E. heros, P. guildinii, and T. limbativentris. An interesting feature of stink bug behavior is the diel rhythm of female response to the male-produced pheromone. In all the species mentioned here, females did not respond during the early hours of the day, but were strongly attracted during the afternoon and evening hours. The reason for this welldefined response pattern is not clear and also differs from other pentatomid species.

\subsubsection{Leptoglossus zonatus (Coreidae)}

The components of the secretion produced by adults of $L$. zonatus in the metathoracic gland were analyzed from whole-body extracts and shown to consist of hexanal (31), 1-hexanol (32), hexyl acetate (33), and hexanoic acid (34). ${ }^{51}$ Each of the four compounds, as well as (E)-2hexenal (25), elicited a dispersive behavior in adults. This latter compound has been found, together with $(E)$-4-oxo2-hexenal (26), in whole-body extracts of nymphs of $L$. zonatus, and was shown, as well as the adult-produced compounds, to elicit dispersive behavior in nymphs. ${ }^{51}$

\subsubsection{Euschistus heros (Pentatomidae)}

A sex pheromone candidate in E. heros was first proposed when male-specific volatiles from this species and its nearctic relative E. obscurus were identified in a collaboration between Brazilian and U.S.-American researchers. Males of E. obscurus produce methyl $(2 E, 4 Z)$ decadienoate (35) and methyl 2,6,10-trimethyltridecanoate (36) as pheromone compounds, and the latter ester was shown to be a major male-specific volatile also in $E$. heros. ${ }^{52}$ Behavioral evidence was contributed later, when Borges and co-workers used a laboratory bioassay to show that a stereoisomeric mixture of this compound was as attractive to $E$. heros females as the odors from live males. ${ }^{53}$ The attractiveness of methyl $(2 E, 4 Z)$-decadienoate (35), methyl 2,6,10-trimethyldodecanoate (37) and methyl 2,6,10-trimethyltridecanoate (36) has also been confirmed in the field. ${ }^{54}$

\subsubsection{Piezodorus guildinii (Pentatomidae)}

Some confusion was produced, when methyl 2,6,10-trimethyltridecanoate was first brought out in field traps in Brazil. Initially targeted at Euschistus heros, the main 
species caught in these traps was $P$. guildinii, together with lower numbers of $E$. heros and other stink bug species.$^{55} \mathrm{In}$ a later study, methyl 2,6,10-trimethyltridecanoate (36) and the related compound methyl 2,6,10-trimethyldodecanoate (37) were found in airborne extracts of $P$. guildinii and claimed to be the pheromone of this species. ${ }^{56}$ However, a recent investigation confirmed the male-produced sex pheromone of $P$. guildinii to be $(7 R)$ - $\beta$-sesquiphellandrene (38). ${ }^{57}$ Compounds $\mathbf{3 6}$ and $\mathbf{3 7}$ have not been found in extracts during the reinvestigation of this species.

\subsubsection{Thyanta perditor (Pentatomidae)}

Females of $T$. perditor are attracted to methyl $(2 E, 4 Z, 6 Z)$ decatrienoate (39), a thermally unstable compound released by sexually mature conspecific males. ${ }^{49}$ Similar to the situation in Euschistus species, this compound is also part of the sex pheromone of the nearctic congeneric species T. pallidovirens and T. curstator accerra. However, while methyl $(2 E, 4 Z, 6 Z)$-decatrienoate (39) alone is attractive to T. perditor, in the nearctic species the presence of at least one of the sesquiterpene hydrocarbons, $\alpha$-curcumene, zingiberene, or $\beta$-sesquiphellandrene is needed for attractiveness. $^{58}$

\subsubsection{Tibraca limbativentris (Pentatomidae)}

Another sesquiterpene has been identified as the sex pheromone from T. limbativentris. Males produce a mixture of at least three stereoisomers of zingiberenol $\mathbf{4 0}$. The response of females to synthetic mixtures of isomers suggested the $1^{\prime} S$ configuration of the natural compound, although the $1^{\prime} R$ isomers were also attractive..$^{50}$

\section{Related Topics}

\subsection{Behavioral evidence for pheromones}

Evidence for the existence of pheromones based on behavioral studies has been provided for several insect species. In some cases (which are discussed in the previous section) the compounds involved in intraspecific communication have been identified later, while in other cases the structures still remain unknown. These species are listed in table 3, together with a short description and the respective literature references.

\subsubsection{Assassin bugs (Hemiptera: Reduviidae)}

Triatoma infestans is a haematophagous insect with distribution in southern South America. It is considered to be the main vector of Trypanosoma cruzi, a flagellate causing Chagas disease. An aggregation behavior has been described for T. infestans and several other reduviid

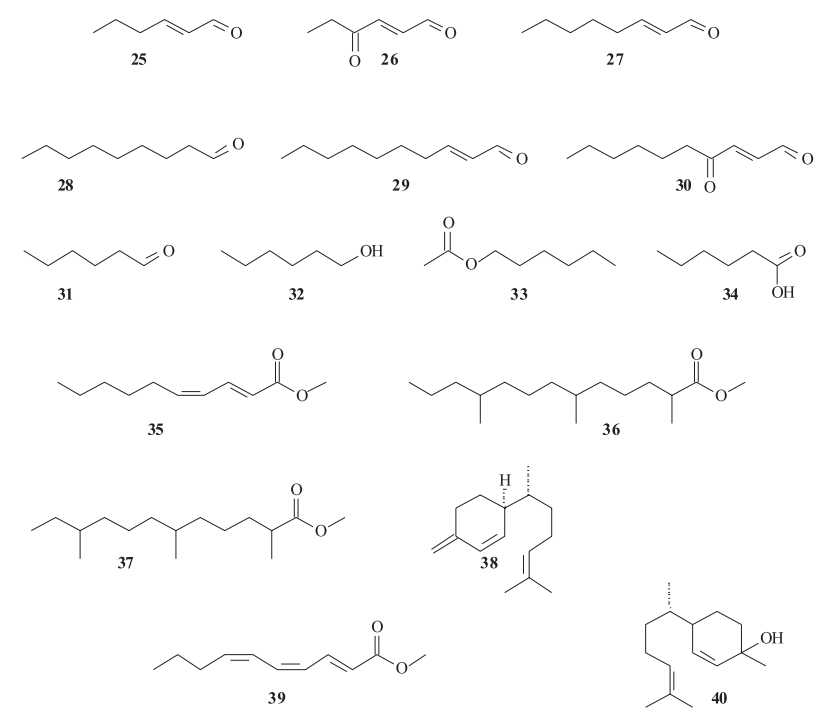

Figure 6. Heteropteran pheromones identified with participation of South American researchers.

species, which are also vectors for T. cruzi. Larvae of T. infestans,${ }^{81,82}$ T. pseudomaculata, ${ }^{83}$ T. sordida, ${ }^{82} T$. guasayana, ${ }^{82}$ Rhodnius prolixus, ${ }^{84}$ and Panstrongylus megistus $^{85}$ are attracted to their faeces. This attraction is not specific, as inter-specific attraction to excrements has been shown for several species. A recent study showed that methylated quinazolines, present in faeces, are attractive to T. infestans. ${ }^{86}$ Another source for an aggregation factor for larvae are their footprints, as has been shown for $T$. infestans ${ }^{87}$ T. pseudomaculata ${ }^{83}$ and P. megistus, ${ }^{85}$ with evidence of cross-attraction in some species.

The existence of a volatile signal releasing an aggregation behavior of adult males has been demonstrated for $T$. infestans. ${ }^{88}$ These volatiles are emitted by copulating pairs and have been shown to be a complex mixture of alcohols, aldehydes, acids, and dipropyl sulfide. ${ }^{89}$ Some of the compounds identified were electrophysiologically active and were also attractive to males and/or females. The role of Brindley's and metasternal glands in chemical communication of $T$. infestans has been studied ${ }^{90}$ and it has been suggested that volatiles released from the metasternal glands are involved in sexual and alarm behavior of this species. ${ }^{90,91}$ Several compounds have been identified from metasternal glands, including 3-pentanone, 2-methylbutanol, and 3-pentanol. ${ }^{91}$ Major volatiles released from Brindley's glands include isobutyric acid, 2-methylbutanol, 3-methylbutanol ${ }^{91}$ as well as the isobutanoates of the latter alcohols. ${ }^{92}$ Behavioral studies suggested both an alarm and defensive role of these compounds. ${ }^{91,92}$ Several short-chain ketones and alcohols were also detected in the metasternal glands of adult female $R$. prolixus, and a possible role in sexual communication of the species was suggested. ${ }^{93}$ 
Table 3. Insect species for which evidence for the use of pheromones has been found

\begin{tabular}{|c|c|c|}
\hline Species & Description & Reference \\
\hline \multicolumn{3}{|l|}{ Hemiptera } \\
\hline $\begin{array}{l}\text { Dactyopius coccus } \\
\text { (Coccoidea) }\end{array}$ & Experiments in an olfactometer demonstrate that females produce a volatile sex pheromone & 59 \\
\hline $\begin{array}{l}\text { Neomegalotomus parvus } \\
\text { (Alydidae) }\end{array}$ & Male-lured traps captured significantly more males than control traps & 60 \\
\hline $\begin{array}{l}\text { Panstrongylus megistus } \\
\text { Rhodnius prolixus } \\
\text { Triatoma spp. } \\
\text { (Reduviidae) }\end{array}$ & See section 4.1.1. & \\
\hline \multicolumn{3}{|l|}{ Hymenoptera } \\
\hline $\begin{array}{l}\text { Atta spp. } \\
\text { (Formicidae) }\end{array}$ & See section 4.1.2. & \\
\hline $\begin{array}{l}\text { Apis mellifera } \\
\text { (Apidae) }\end{array}$ & $\begin{array}{l}\text { Behavioral responses of workers to Dufour gland extracts of the queen and nestmate and } \\
\text { non-nestmate workers were studied. }\end{array}$ & 61 \\
\hline $\begin{array}{l}\text { Bephratelloides pomorum } \\
\text { (Eurytomidae) }\end{array}$ & $\begin{array}{l}\text { Males were attracted to females in field experiments. Headspace volatiles from female } \\
\text { wasps elicited sexual behavior in males. }\end{array}$ & 62,63 \\
\hline $\begin{array}{l}\text { Cotesia flavipes } \\
\text { (Braconidae) }\end{array}$ & $\begin{array}{l}\text { A sex pheromone produced by females in an abdominal gland releases courtship behavior } \\
\text { in males }\end{array}$ & 64 \\
\hline $\begin{array}{l}\text { Melipona seminigra } \\
\text { (Apidae) }\end{array}$ & Bees scent mark a food source by leaving chemicals secreted at the leg tips. & 65 \\
\hline $\begin{array}{l}\text { Nannotrigona testaceicornis } \\
\text { (Apidae) }\end{array}$ & $\begin{array}{l}\text { Bees preferred feeders where nestmates had fed before over unused feeders. The scent } \\
\text { marks are left behind independent of food uptake, and were deduced to be cues rather } \\
\text { than signals. }\end{array}$ & 66 \\
\hline $\begin{array}{l}\text { Vespula germanica } \\
\text { (Vespidae) }\end{array}$ & Head extracts of workers proved attractive to conspecifics. & 67 \\
\hline \multicolumn{3}{|l|}{ Isoptera } \\
\hline $\begin{array}{l}\text { Constrictotermes cyphergaster } \\
\text { (Termitidae) }\end{array}$ & $\begin{array}{l}\text { Apart from the trail pheromone produced by sternal glands, fecal droplets are an additional } \\
\text { source for trail marking }\end{array}$ & 68 \\
\hline $\begin{array}{l}\text { Coptotermes gestroi } \\
\text { Heterotermes tenuis } \\
\text { (Rhinotermitidae) }\end{array}$ & Existence and specificity of trail pheromones was demonstrated & 69 \\
\hline $\begin{array}{l}\text { Nasutitermes corniger } \\
\text { Nasutitermes ephratae } \\
\text { (Termitidae) }\end{array}$ & $\begin{array}{l}\text { Caste, colony and species specificity of the trail pheromone of these two sympatric } \\
\text { species was demonstrated }\end{array}$ & 70 \\
\hline \multicolumn{3}{|l|}{ Lepidoptera } \\
\hline $\begin{array}{l}\text { Cerconota annonella } \\
\text { (Noctuidae) }\end{array}$ & The calling behavior of females is described. Males are attracted to virgin females & 71 \\
\hline $\begin{array}{l}\text { Pseudaletia sequax } \\
\text { (Noctuidae) }\end{array}$ & $\begin{array}{l}\text { The calling behavior of females is described. Effects of pupal period and age on the } \\
\text { calling behavior were studied. }\end{array}$ & 72 \\
\hline $\begin{array}{l}\text { Thyrinteina arnobia } \\
\text { (Geometridae) }\end{array}$ & $\begin{array}{l}\text { The calling behavior of females is described. The effects of different diets on the calling } \\
\text { behavior were studied }\end{array}$ & 73 \\
\hline \multicolumn{3}{|l|}{ Coleoptera } \\
\hline $\begin{array}{l}\text { Liogenys fuscus } \\
\text { (Scarabeidae) }\end{array}$ & Calling behavior was observed in laboratory & 74 \\
\hline $\begin{array}{l}\text { Schwarzerion holochlorium } \\
\text { (Cerambycidae) }\end{array}$ & Experimental evidence for an alarm pheromone is provided. & 75 \\
\hline $\begin{array}{l}\text { Steirastoma breve } \\
\text { (Cerambycidae) }\end{array}$ & $\begin{array}{l}\text { EAG responses were recorded for both sexes when antennae were stimulated with male- } \\
\text { produced volatiles }\end{array}$ & 76 \\
\hline $\begin{array}{l}\text { Sternechus subsignatus } \\
\text { (Curculionidae) }\end{array}$ & $\begin{array}{l}\text { Olfactometer assays provided evidence for the existence of a male-produced aggregation } \\
\text { pheromone. Five male-specific compounds were detected in gas chromatographic analysis. }\end{array}$ & 77 \\
\hline
\end{tabular}


Table 3. continuation

\begin{tabular}{ll}
\hline $\begin{array}{l}\text { Species } \\
\text { Diptera }\end{array}$ & Description \\
\hline $\begin{array}{l}\text { Aedes aegypti } \\
\text { (Culicidae) }\end{array}$ & Lekking behavior is modulated by an aggregation pheromone \\
$\begin{array}{l}\text { Dermatobia hominis } \\
\text { (Oestridae) }\end{array}$ & Cuticular extracts from females, but not from males, induced copulatory behavior in males \\
$\begin{array}{l}\text { Stomoxys calcitrans } \\
\text { (Muscidae) }\end{array}$ & Females are attracted to faeces and chloroform-methanol extracts of faeces \\
\hline
\end{tabular}

\subsubsection{Leafcutter ants}

The role of chemicals in the communication of some Atta species has been investigated by several Venezuelan and Brazilian research groups. The alarm behavior and possible nestmate recognition signals were studied in A. bisphaerica, ${ }^{94}$ A. capiguara,${ }^{94}$ A. cephalota,${ }^{95}$ A. laevigata, ${ }^{95,96}$ A. opaciceps, ${ }^{97}$ A. sexdens rubropilosa,${ }^{98}$ and $A$. sexdens sexdens. ${ }^{97}$ In most species, the main source of compounds involved in alarm behavior and/or nestmate recognition could be localized in the head and the compounds so far identified include 4-methyl-3-heptanol, 4-methyl-3-heptanone and other related compounds. ${ }^{99}$

\subsection{Syntheses of pheromones}

Pheromones need to be synthesized for two reasons. First, to provide authentic reference material needed for unambiguous identification of the natural compound by comparing their analytical data, such as gas chromatographic retention times and mass spectra. Second, to provide the material necessary for the evaluation of their effect on insect behavior in laboratory bioassays or under natural conditions in the field. In this context, syntheses have to be developed, which lead in good yields to multi-gram amounts of the desired compound(s). Furthermore, as pheromones often occur as pure or as defined mixtures of stereoisomers, special care must be taken to develop routes which lead with high selectivity to the desired geometric and/or absolute configuration. The initial synthesis of a chiral pheromone compound is often aimed at obtaining a mixture of isomers, as the main goal is the verification of the correct carbon skeleton and position of the functional groups. Later investigations then work out stereoselective pathways to the target molecules.

The syntheses of pheromone compounds developed by Brazilian research groups have been reviewed most recently ${ }^{100}$ and are not further discussed here. Another review presented by Brazilian authors summarized the syntheses of naturally occurring medium-sized lactones. ${ }^{101}$ Syntheses of pheromones carried out outside Brazil are scarce and include (E)-9-dodecenyl acetate, a pheromone compound of the pine shoot moth Rhyacionia buoliana, ${ }^{102}$ the female-produced sex pheromone of the scarabaeid beetle Popillia japonica, (4R,5Z)-5-tetradecen-4-olide [ $(R)$ japonilure], ${ }^{103}$ both in Chile, and methyl $(E)$-6-noneoate, a male-produced compound of the fruit fly Ceratitis capitata, in Argentina. ${ }^{104}$

\subsection{Other selected topics}

The chemical ecology of the bird cherry-oat aphid, Rhopalosiphum padi, has been investigated in a number of studies in and outside South America. Chilean researchers demonstrated that the attraction of $R$. padi to the host plant oat is mediated by plant volatiles. ${ }^{105}$ Furthermore, they showed that volatiles emitted by an aphid-plant complex with a high aphid density, have a repellent effect on the aphids. The compounds responsible for the repellence were identified as 6-methyl-5-hepten-2-one, $(R)$ - and $(S)$ 6-methyl-5-hepten-2-ol in a 1:3 ratio, and 2-tridecanone. ${ }^{106}$ However, it has not been established, whether these compounds are produced by the plant as a defensive reaction (which would hence be an allomone) or if it is a pheromone produced by the insects as a reaction to a too high population density.

Fruit flies of the genus Anastrepha (Diptera: Tephritidae) are native to Central and South America, and include 150 to 200 species. Anastrepha spp. are pests of many fruit and vegetable crops, causing serious losses, either by direct damage or by facilitating microbial infections of the host plant. In a study led by Brazilian scientists, the identification and behavioral activity of volatile compounds from males of the South American fruit fly, A. fraterculus, was presented. Using different extraction and trapping techniques, it was shown that calling males release compounds similar to those involved in the chemical communication of the Mexican fruit fly, A. ludens, and the Caribbean fruit fly, A. suspensa, including anastrephin, epianastrephin, $(E, E)$-suspensolide, $(E, Z)-\alpha$-farnesene, $(Z, E)-\alpha$-farnesene, limonene, and (Z)- $\beta$-ocimene. ${ }^{107}$ The salivary glands from virgin mature 
males attracted virgin mature females, and contained the same isomers of farnesene and suspensolide, as well as alkylated pyrazines. ${ }^{107}$ However, synthetic compounds were not used in behavioral assays. In another study, Argentine researchers investigated the lekking behavior of male $A$. fraterculus and found that pheromone calling activity was positively related with copulatory success. ${ }^{108}$

Interactions between aggregation pheromones and host volatiles have been investigated in Venezuela for two weevil species. Rhynchophorus palmarum is a neotropical pest of palms, attacking mostly injured trees. Jaffe and co-workers reported that volatiles from the host plant (ethanol, ethyl acetate, pentane, hexanal and isopentanol) were attractive in olfactometer tests, but no long-range attraction was observed in the field. They also found that the aggregation pheromone [ $(E)$-6-methyl-2-hepten4-ol, rhynchophorol] only attracts males when either the complete bouquet of plant volatiles or ethyl acetate alone is present. ${ }^{109}$ Metamasius hemipterus is a serious sugarcane pest distributed throughout Central and South America, the West Indies, Mexico and Florida (U.S.). The attraction of adult beetles toward host plant parts in an olfactometer was reported, ${ }^{110}$ as well as captures in field traps baited with different mixtures of plant parts and the aggregation pheromone, an 8:1 mixture of 4-methyl-5nonanol and 2-methyl-4-heptanol. It was concluded that the pheromone and host volatiles act synergistically to attract M. hemipterus adults, like in other related weevil species.

\section{Conclusions}

In this article, we review the research related to insect pheromones done by or done in collaboration with South American researchers, without addressing research in which groups from the rest of Latin America is involved and excluding all other fields of Chemical Ecology, e.g. insect allelochemicals (including insect-plant interactions) or semiochemicals of species not belonging to the class Insecta. Without doubt, Chemical Ecology has experienced a strong growth during the last few years in Latin America, and there is a great research activity ongoing in all of its areas. The studies are motivated by the prospect of gaining a better understanding of ecological relationships and/or the intention to develop environmentally benign methods of pest control. This latter point is of increasing importance and projects need to have more and more a strong component towards an (economically important) application to be eligible for funding. South American countries generally invert a relative low percentage of their GDP in research \& development, which together with an increasing overall number of scientists leads to an ever-increasing competition for research funds. In order to strengthen Chemical Ecology in Latin America and taking advantage of the recent growth of the field, the foundation of a Latin American Association of Chemical Ecology is proposed. The formation of a regional society would facilitate the diffusion of news and events among the members of the community and promote the interactions between researchers. Important problems to be addressed could be identified and dealt with more easily. The formality of an association would also help to establish Chemical Ecology research in the different countries and lead to a better positioning of the field in the perception of decisionmakers in science policy. Furthermore, the organization of regional meetings of Chemical Ecology is a logical consequence and would contribute to a more widespread diffusion of research results and their importance for society. We envisage a first meeting to be held in 2010 in Montevideo, Uruguay, and encourage all researchers to support the Latin American Association of Chemical Ecology.

\section{Acknowledgments}

The authors gratefully acknowledge financial support for international cooperation provided by CNPq, Brazil (PROSUL Proc.No.: 490368/2006-9, Brazil-UruguayChile).

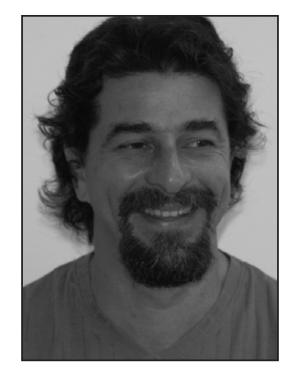

Andrés González is an Assistant Professor at the Faculty of Chemistry of the Universidad de la República of Uruguay. He obtained his doctorate degree $(P h D)$ at Cornell University (USA) in 1999. His research interests cover the chemical and behavioral aspects of insect chemical communication and defense, focusing primarily in intraand interspecific chemical signals of regional agricultural pests. He currently teaches Introductory Biology and Chemical Ecology courses.

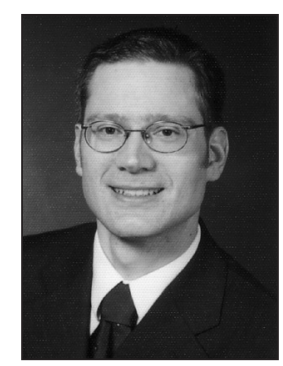

Jan Bergmann is Associate Professor at the Institute of Chemistry of the Pontifical Catholic University of Valparaíso, Chile. He completed his doctoral studies (Dr. rer. nat.) in 2002 at the University of Hamburg. His research interests are the identification and synthesis of 
biologically active natural compounds, with a focus on insect pheromones. He teaches Organic Chemistry and Chemical Ecology courses, and is currently Director of the doctorate program of the Institute.

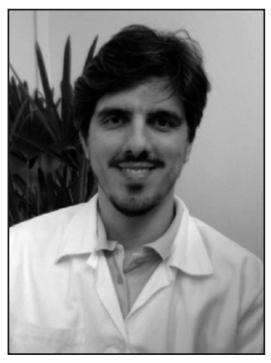

Paulo H. G. Zarbin is Associate Professor of the Department of Chemistry at the Federal University of Parana (UFPR), Brazil, where served as chair of the graduate program in chemistry for the years 2002-2004. Obtained his PhD in 1998 at Federal University of São Carlos, with part of his thesis developed at the National Institute of Sericultural and Entomological Science, in Tsukuba, Japan. He is currently councilor of the International Society of Chemical Ecology, and member of the editorial board of the Journal of Chemical Ecology. His main research interest is focused on the identification, synthesis, biosynthesis and field evaluation of insect pheromones and other semiochemicals.

\section{References}

1. http://ddp-ext.worldbank.org, accessed in April, 2008.

2. Rodriguez, L. C.; Niemeyer, H. M.; Crop Prot. 2005, 24, 615.

3. Butenandt, A.; Beckmann, R.; Stamm, D.; Hecker, E.; Z. Naturforsch., B: Chem. Sci. 1959, 14, 283.

4. Millar, J. G.; Haynes, K., Methods in Chemical Ecology Chemical Methods, Kluwer: Dordrecht, 1998.

5. Cross, J. H.; Byler, R. C.; Ravid, U.; Silverstein, R. M.; Robinson, S. W.; Baker, P. M.; de Oliveira, J. S.; Jutsum, A. R.; Cherett, J. M.; J. Chem. Ecol. 1979, 5, 187.

6. ISI Web of Knowledge, Thomson Scientific, accessed in April, 2008.

7. www.pherolist.slu.se, accessed in April, 2008.

8. Millar, J. G.; Annu. Rev. Entomol. 2000, 45, 575.

9. Cichon, L. I.; Trematerra, P.; Coracini, M. D. A.; Fernandez, D.; Bengtsson, M.; Witzgall, P.; J. Econ. Entomol. 2004, 97, 946.

10. Nuñez, S.; De Vlieger, J. J.; Rodriquez, J. J.; Persoons, C. J.; Scatoni, I.; J. Chem. Ecol. 2002, 28, 425.

11. Hall, D. R.; Beevor, P. S.; Campion, D. G.; Chamberlain, D. J.; Cork, A.; White, R. D.; Almestar, A.; Henneberry, T. J.; Tetrahedron Lett. 1992, 33, 4811.

12. Svatos, A.; Kalinova, B.; Kindl, J.; Kuldova, J.; Hovorka, O.; Do Nascimento, R. R.; Oldham, N. J.; Collect. Czech. Chem. Commun. 2001, 66, 1682.

13. Leal, W. S.; Bento, J. M. S.; Murata, Y.; Ono, M.; Parra, J. R. P.; Vilela, E. F.; J. Chem. Ecol. 2001, 27, 2041.
14. Cork, A.; Lobos, E. A.; Entomol. Exp. Appl. 2003, 107, 201.

15. Zarbin, P. H. G.; Lorini, L. M.; Ambrogi, B. G.; Vidal, D. M.; Lima, E. R.; J. Chem. Ecol. 2007, 33, 555.

16. Subchev, M.; Toshova, T.; Stanimirova, L.; Stan, G.; Embacher, G.; Francke, W.; Reckziegel, A.; Ferreira, J. T.; Priesner, E.; J. Chem. Ecol. 2000, 26, 487.

17. Cabrera, A.; Eiras, A. E.; Gries, G.; Gries, R.; Urdaneta, N.; Miras, B.; Badji, C.; Jaffe, K.; J. Chem. Ecol. 2001, 27, 2097.

18. Unelius, C. R.; Eiras, A.; Witzgall, P.; Bengtsson, M.; Kovaleski, A.; Vilela, E. F.; BorgKarlson, A. K.; Tetrahedron Lett. 1996, 37,1505 .

19. Leal, W. S.; Parra-Pedrazzoli, A. L.; Cosse, A. A.; Murata, Y.; Bento, J. M. S.; Vilela, E. F.; J. Chem. Ecol. 2006, 32, 155.

20. Moreira, J. A.; McElfresh, J. S.; Millar, J. G.; J. Chem. Ecol. 2006, 32, 169.

21. Attygalle, A. B.; Jham, G. N.; Svatos, A.; Frighetto, R. T. S.; Meinwald, J.; Vilela, E. F.; Ferrara, F. A.; UchoaFernandes, M. A.; Tetrahedron Lett. 1995, 36, 5471.

22. Svatos, A.; Attygalle, A. B.; Jham, G. N.; Frighetto, R. T. S.; Vilela, E. F.; Saman, D.; Meinwald, J.; J. Chem. Ecol. 1996, 22,787 .

23. Attygalle, A. B.; Jham, G. N.; Svatos, A.; Frighetto, R. T. S.; Ferrara, F. A.; Vilela, E. F.; UchoaFernandes, M. A.; Meinwald, J.; Bioorg. Med. Chem. 1996, 4, 305.

24. Batista-Pereira, L. G.; Stein, K.; de Paula, A. F.; Moreira, J. A.; Cruz, I.; Figueiredo, M. D.; Perri, J.; Correa, A. G.; J. Chem. Ecol. 2006, 32, 1085.

25. Zagatti, P.; Lucas, P.; Genty, P.; Arango, S.; Malosse, C.; Tellier, F.; J. Chem. Ecol. 1996, 22, 1103.

26. Bosa, C. F.; Prado, A. M. C.; Fukumoto, T.; Bengtsson, M.; Witzgall, P.; Entomol. Exp. Appl. 2005, 114, 137.

27. Francke, W.; Dettner, K. In Chemistry of Pheromones and Other Semiochemicals II; Schulz, S., eds.; Springer: Berlin, 2005, ch. 3.

28. Leal, W. S.; Bento, J. M. S.; Vilela, E. F.; Dellalucia, T. M. C.; Experientia 1994, 50, 853.

29. GiblinDavis, R. M.; Gries, R.; Gries, G.; PenaRojas, E.; Pinzon, I.; Pena, J. E.; Perez, A. L.; Pierce, H. D.; Oehlschlager, A. C.; J. Chem. Ecol. 1997, 23, 2287.

30. Zarbin, P. H. G.; Moreira, M. A. B.; Haftmann, J.; Francke, W.; Oliveira, A. R. M.; J. Braz. Chem. Soc. 2007, 18, 1048.

31. Zarbin, P. H. G.; Arrigoni, E. D.; Reckziegel, A.; Moreira, J. A.; Baraldi, P. T.; Vieira, P. C.; J. Chem. Ecol. 2003, 29, 377.

32. Quiroz, A.; Palma, R.; Etcheverria, P.; Navarro, V.; Rebolledo, R.; Environ. Entomol. 2007, 36, 272.

33. Leal, W. S.; Annu. Rev. Entomol. 1998, 43, 39.

34. Zarbin, P. H. G.; Leal, W. S.; Avila, C. J.; Oliveira, L. J.; Tetrahedron Lett. 2007, 48, 1991; Leal, W. S.; Oehlschlager, A. C.; Zarbin, P. H. G.; Hidalgo, E.; Shannon, P. J.; Murata, Y.; Gonzalez, L.; Andrade, R.; Ono, M.; J. Chem. Ecol. 2003, 29, 15.

35. Rochat, D.; Ramirez-Lucas, P.; Malosse, C.; Aldana, R.; Kakul, T.; Morin, J. P.; J. Chromatogr., A 2000, 885, 433. 
36. Gonzalez-Audino, P.; Villaverde, R.; Alfaro, R.; Zerba, E.; J. Econ. Entomol. 2005, 98, 1506.

37. Liguori, P.; Zerba, E.; Alzogaray, R.; Gonzalez-Audino, P.; J. Chem. Ecol. 2008, 34, 1446.

38. Keeling, C. I.; Plettner, E.; Slessor, K. N. In Chemistry of Pheromones and Other Semiochemicals I; Schulz, S., ed.; Springer: Berlin, 2004, ch. 4.

39. do Nascimento, R. R. D.; Morgan, E. D.; Moreira, D. D. O.; Dellalucia, T. M. C.; J. Chem. Ecol. 1994, 20, 1719.

40. Oliveira, J. S.; Martinez, O. M. M.; Carnieri, M.; Vilela, E. F.; Reis, H. O.; An. Soc. Entomol. Brasil 1990, 19, 143.

41. Torres-Contreras, H.; Olivares-Donoso, R.; Niemeyer, H. M.; J. Chem. Ecol. 2007, 33, 435.

42. Holldobler, B.; Janssen, E.; Bestmann, H. J.; Leal, I. R.; Oliveira, P. S.; Kern, F.; Konig, W. A.; J. Comp. Physiol. A Neuroethol. Sens. Neural Behav. Physiol. 1996, 178, 47.

43. Jarau, S.; Hrncir, M.; Zucchi, R.; Barth, F. G.; J. Comp. Physiol. A Neuroethol. Sens. Neural Behav. Physiol. 2004, 190, 233.

44. Jarau, S.; Schulz, C. M.; Hrncir, M.; Francke, W.; Zucchi, R.; Barth, F. G.; Ayasse, M.; J. Chem. Ecol. 2006, 32, 1555.

45. Schorkopf, D. L. P.; Jarau, S.; Francke, W.; Twele, R.; Zucchi, R.; Hrncir, M.; Schmidt, V. M.; Ayasse, M.; Barth, F. G.; Proc. R. Soc. B 2007, 274, 895.

46. Millar, J. G. In Chemistry of Pheromones and Other Semiochemicals II; Schulz, S., ed.; Springer: Berlin, 2005, ch. 2.

47. Moraes, M. C. B.; Pareja, M.; Laumann, R. A.; Borges, M.; Neotrop. Entomol. 2008, 37, 489.

48. Borges, M.; Aldrich, J. R.; Experientia 1992, 48, 893; Zarbin, P. H. G.; Borges, M.; dos Santos, A. A.; de Oliveira, A. R. M.; Simonelli, F.; Marques, F. D.; J. Braz. Chem. Soc. 2000, 11, 424; Pareja, M.; Borges, M.; Laumann, R. L. A.; Moraes, M. C. B.; J. Insect Physiol. 2007, 53, 639.

49. Moraes, M. C. B.; Millar, J. G.; Laumann, R. A.; Sujii, E. R.; Pires, C. S. S.; Borges, M.; J. Chem. Ecol. 2005, 31, 1415.

50. Borges, M.; Birkett, M.; Aldrich, J. R.; Oliver, J. E.; Chiba, M.; Murata, Y.; Laumann, R. A.; Barrigossi, J. A.; Pickett, J. A.; Moraes, M. C. B.; J. Chem. Ecol. 2006, 32, 2749.

51. Leal, W. S.; Panizzi, A. R.; Niva, C. C.; J. Chem. Ecol. 1994, 20, 1209.

52. Borges, M.; Aldrich, J. R.; J. Chem. Ecol. 1994, 20, 1095; Aldrich, J. R.; Oliver, J. E.; Lusby, W. R.; Kochansky, J. P.; Borges, M.; J. Chem. Ecol. 1994, 20, 1103.

53. Borges, M.; Mori, K.; Costa, M. L. M.; Sujii, E. R.; J. Appl. Entomol. 1998, 122, 335.

54. Costa, M. L. M.; Borges, M.; Vilela, E. F.; de Marco Jr., P.; Lima, E. R.; An. Soc. Entomol. Brasil 2000, 29, 413; Zhang, A.; Borges, M.; Aldrich, J. R.; Camp, M.; Neotrop. Entomol. 2003, 32, 713 .

55. Borges, M.; Schmidt, F. G. V.; Sujii, E. R.; Medeiros, M. A.; Mori, K.; Zarbin, P. H. G.; Ferreira, J. T. B.; Physiol. Entomol. 1998, 23, 202.
56. Borges, M.; Zarbin, P. H. G.; Ferreira, J. T. B.; Da Costa, M. L. M.; J. Chem. Ecol. 1999, 25, 629.

57. Borges, M.; Millar, J. G.; Laumann, R. A.; Moraes, M. C. B.; J. Chem. Ecol. 2007, 33, 1235.

58. McBrien, H. L.; Millar, J. G.; Rice, R. E.; McElfresh, J. S.; Cullen, E.; Zalom, F. G.; J. Chem. Ecol. 2002, 28, 1797.

59. Rodriguez, L. C.; Faundez, E. H.; Niemeyer, H. M.; Eur. J. Entomol. 2005, 102, 305.

60. Ventura, M. U.; Panizzi, A. R.; Braz. Arch. Biol. Technol. 2004, $47,531$.

61. Abdalla, F. C.; da Cruz-Landim, C.; Sociobiology 2001, 37, 673.

62. Leal, W. S.; Moura, J. I. L.; Bento, J. M. S.; Vilela, E. F.; Pereira, P. B.; J. Chem. Ecol. 1997, 23, 1281.

63. do Nascimento, R. R.; de Lima, I. S.; de Mendonca, C. M. L.; da Silva, L. C. N.; Duarte, A. G.; Sant'Ana, A. E. G.; Pestic. Sci. 1998, 54, 311 .

64. de Freitas, M. D. T.; Mendonca, A. D.; do Nascimento, R. R.; Sant'ana, A. E. G.; Physiol. Entomol. 2004, 29, 183.

65. Hrncir, M.; Jarau, S.; Zucchi, R.; Barth, F. G.; Apidologie 2004, 35,3 .

66. Schmidt, V. M.; Zucchi, R.; Barth, F. G.; Apidologie 2005, 36, 285.

67. D’Adamo, P.; Lozada, M.; Corley, J. C.; J. Insect Behav. 2004, 17, 809.

68. Souto, L.; Kitayama, K.; Sociobiology 2000, 35, 367.

69. Arab, A.; Costa-Leonardo, A. M.; Batista-Pereira, L. G.; dos Santos, M. G.; Correa, A. G.; Blanco, Y. C.; Sociobiology 2004, 43,377 .

70. Arab, A.; Issa, S.; Alfonzo, D.; Jaffe, K.; Sociobiology 2006, 47,345 .

71. da Silva, E. L.; de Carvalho, C. M.; do Nascimento, R. R.; Mendonca, A. L.; da Silva, C. E.; Goncalves, G. B.; de Freitas, M. D. T.; Sant'Ana, A. E. G.; Ethology 2006, 112, 971.

72. Almeida, A. A.; Lima, E. R.; Reis, R.; Ethology 2008, 114, 499.

73. Batista-Pereira, L. G.; Wilcken, C. F.; Neto, S. D. P.; Marques, E. N.; Neotrop. Entomol. 2004, 33, 21.

74. Rodrigues, S. R.; Barbosa, C. D.; Puker, A.; Abot, A. R.; Ide, S.; Rev. Bras. Entomol. 2008, 52, 637.

75. Greeney, H. F.; DeVries, P. J.; Coleopt. Bull. 2004, 58, 642.

76. Liendo, C.; Morillo, F.; Sanchez, P.; Munoz, W.; Guerra, J.; Cabrera, A.; Hernandez, J. V.; Fla. Entomol. 2005, 88, 117.

77. Ambrogi, B. G.; Zarbin, P. H. G.; J. Appl. Entomol. 2008, $132,54$.

78. Cabrera, M.; Jaffe, K.; J. Am. Mosq. Control. Assoc. 2007, $23,1$.

79. Gomes, C. C. G.; Trigo, J. R.; Eiras, A. E.; J. Chem. Ecol. 2008, $34,636$.

80. Carlson, D. A.; Alzogaray, R. A.; Hogsette, J. A.; J. Med. Entomol. 2000, 37, 957.

81. Figueiras, A. N. L.; Kenigsten, A.; Lazzari, C. R.; J. Insect Physiol. 1994, 40, 311; Lorenzo, M. G.; Lazzari, C. R.; J. Insect Physiol. 1996, 42, 903. 
82. Figueiras, A. N. L.; Lazzari, C. R.; Mem. Inst. Oswaldo Cruz 1998, 93, 133.

83. Vitta, A. C. R.; Figueiras, A. N.; Lazzari, C. R.; Diotaiuti, L.; Lorenzo, M. G.; Mem. Inst. Oswaldo Cruz 2002, 97, 865.

84. Figueiras, A. N. L.; Lazzari, C. R.; Mem. Inst. Oswaldo Cruz 2002, 97, 569.

85. Pires, H. H. R.; Lorenzo, M. G.; Diotaiuti, L.; Lazzari, C. R.; Figueiras, A. N. L.; Acta Trop. 2002, 81, 47.

86. Alzogaray, R. A.; Fontan, A.; Camps, F.; Masuh, H.; Santo Orihuela, P.; Fernandez, D.; Cork, A.; Zerba, E.; Molecules 2005, 10, 1190.

87. Figueiras, A. N. L.; Lazzari, C. R.; Physiol. Entomol. 1998, 23, 33.

88. Manrique, G.; Lazzari, C. R.; Mem. Inst. Oswaldo Cruz 1995, 90, 645; Sanchez, M.; Manrique, G.; Lazzari, C. R.; Mem. Inst. Oswaldo Cruz 1995, 90, 649 .

89. Fontan, A.; Audino, P. G.; Martinez, A.; Alzogaray, R. A.; Zerba, E. N.; Camps, F.; Cork, A.; J. Med. Entomol. 2002, 39, 191.

90. Crespo, J. G.; Manrique, G.; J. Insect Physiol. 2007, 53, 708.

91. Manrique, G.; Vitta, A. C. R.; Ferreira, R. A.; Zani, C. L.; Unelius, C. R.; Lazzari, C. R.; Diotaiuti, L.; Lorenzo, M. G.; J. Chem. Ecol. 2006, 32, 2035.

92. Audino, P. G.; Alzogaray, R. A.; Vassena, C.; Masuh, H.; Fontan, A.; Gatti, P.; Martinez, A.; Camps, F.; Cork, A.; Zerba, E.; J. Vect. Ecol. 2007, 32, 75.

93. Pontes, G. B.; Bohman, B.; Unelius, C. R.; Lorenzo, M. G.; J. Chem. Ecol. 2008, 34, 450.

94. Hughes, W. O. H.; Howse, P. E.; Vilela, E. F.; Goulson, D.; Physiol. Entomol. 2001, 26, 165.

95. Hernandez, J. V.; Goitia, W.; Osio, A.; Cabrera, A.; Lopez, H.; Sainz, C.; Jaffe, K.; Anim. Behav. 2006, 71, 945.

96. Whitehouse, M. E. A.; Jaffe, K.; Insectes Sociaux 1995, 42, 157; Hernandez, J. V.; Lopez, H.; Jaffe, K.; J. Insect Physiol. 2002, 48, 287.

97. Francelino, M. R. V.; de Lima, A.; Do Nascimento, M. R. R.; De Mendonca, F. A. C.; Da Silva, E. L.; De Freitas, M.; Cabral, C. R.; Da Silva, C. E.; Ribeiro, J. H. S.; Santana, A. E. G.; Physiol. Entomol. 2008, 33, 37.
98. Bento, J. M. S.; Della Lucia, T. M. C.; Do Nascimento, R. R.; Bergmann, J.; Morgan, E. D.; Physiol. Entomol. 2007, 32, 283; do Nascimento, R. R.; Morgan, E. D.; Billen, J.; Schoeters, E.; Dellalucia, T. M. C.; Bento, J. M. S.; J. Chem. Ecol. 1993, 19, 907.

99. Hernandez, J. V.; Cabrera, A.; Jaffe, K.; J. Chem. Ecol. 1999, $25,2433$.

100. Zarbin, P. H. G.; Villar, J.; Correa, A. G.; J. Braz. Chem. Soc. 2007, 18, 1100; Zarbin, P. H. G.; Princival, J. L.; de Lima, E. R.; dos Santos, A. A.; Ambrogio, B. G.; Oliveira, A. R.; Tetrahedron Lett. 2004, 45, 239; Zarbin, P. H. G.; Cruz, W. D.; Ferreira, J. T. B.; J. Braz. Chem. Soc. 1998, 9, 511.

101. Ferraz, H. M. C.; Bombonato, F. I.; Sano, M. K.; Longo, L. S.; Quim. Nova 2008, 31, 885.

102. Belmar, J.; Tellez, J.; Baeza, J.; Freer, J.; Z. Naturforsch., B: Chem. Sci. 2000, 55, 583.

103. Salasreyes, V.; Z. Naturforsch., B: Chem. Sci. 1995, 50, 1537.

104. Gastaminza, A. E.; Ferracutti, N. N.; Pieroni, O. I.; An. Asoc. Quim. Argent. 1992, 80, 373.

105. Quiroz, A.; Niemeyer, H. M.; J. Chem. Ecol. 1998, 24, 113.

106. Quiroz, A.; Pettersson, J.; Pickett, J. A.; Wadhams, L. J.; Niemeyer, H. M.; J. Chem. Ecol. 1997, 23, 2599; Quiroz, A.; Niemeyer, H. M.; J. Chem. Ecol. 1998, 24, 361.

107. Lima, I. S.; House, P. E.; do Nascimento, R. R.; J. Braz. Chem. Soc. 2001, 12, 196.

108. Segura, D.; Petit-Marty, N.; Sciurano, R.; Vera, T.; Calcagno, G.; Fla. Entomol. 2007, 90, 154.

109. Jaffe, K.; Sanchez, P.; Cerda, H.; Hernandez, J. V.; Jaffe, R.; Urdaneta, N.; Guerra, G.; Martinez, R.; Miras, B.; J. Chem. Ecol. 1993, 19, 1703.

110. Cerda, H.; Fernandez, G.; Lopez, A.; Varga, J.; Fla. Entomol. 1999, 82, 103.

Received: November 12, 2008 Web Release Date: July 23, 2009 